\title{
A molecular phylogeny of Alpine subterranean Trechini (Coleoptera: Carabidae)
}

\author{
Arnaud Faille ${ }^{1^{*}}$, Achille Casale ${ }^{2}$, Michael Balke ${ }^{1}$ and Ignacio Ribera ${ }^{3}$
}

\begin{abstract}
Background: The Alpine region harbours one of the most diverse subterranean faunas in the world, with many species showing extreme morphological modifications. The ground beetles of tribe Trechini (Coleoptera, Carabidae) are among the best studied and widespread groups with abundance of troglobionts, but their origin and evolution is largely unknown.

Results: We sequenced $3.4 \mathrm{~Kb}$ of mitochondrial (cox1, rrnL, trnL, nad1) and nuclear (SSU, LSU) genes of 207 specimens of 173 mostly Alpine species, including examples of all subterranean genera but two plus a representation of epigean taxa. We applied Bayesian methods and maximum likelihood to reconstruct the topology and to estimate divergence times using a priori rates obtained for a related ground beetle genus. We found three main clades of late Eocene-early Oligocene origin: (1) the genus Doderotrechus and relatives; (2) the genus Trechus sensu lato, with most anisotopic subterranean genera, including the Pyrenean lineage and taxa from the Dinaric Alps; and (3) the genus Duvalius sensu lato, diversifying during the late Miocene and including all subterranean isotopic taxa. Most of the subterranean genera had an independent origin and were related to epigean taxa of the same geographical area, but there were three large monophyletic clades of exclusively subterranean species: the Pyrenean lineage, a lineage including subterranean taxa from the eastern Alps and the Dinarides, and the genus Anophthalmus from the northeastern Alps. Many lineages have developed similar phenotypes independently, showing extensive morphological convergence or parallelism.

Conclusions: The Alpine Trechini do not form a homogeneous fauna, in contrast with the Pyrenees, and show a complex scenario of multiple colonisations of the subterranean environment at different geological periods and through different processes. Examples go from populations of an epigean widespread species going underground with little morphological modifications to ancient, geographically widespread lineages of exclusively subterranean species likely to have diversified once fully adapted to the subterranean environment.
\end{abstract}

\section{Background}

Different Arthropod lineages have successfully colonised subterranean environments, prevalent among them are aquatic and terrestrial crustaceans, arachnids, myriapods and insects, in particular Coleoptera [1]. In the western Palaearctic, two groups of Coleoptera include the majority of the underground diversity: the tribes Trechini (family Carabidae) and Leptodirini (family Leiodidae), with hundreds of species with different degrees of morphological modifications assumed to be adaptations to the subterranean environment - different degrees of "troglomorphism"

\footnotetext{
* Correspondence: arnaud1140@yahoo.fr

${ }^{1}$ Zoologische Staatsammlung, Muenchhausenstrasse 21, Munich 81247, Germany

Full list of author information is available at the end of the article
}

[2-4]. The high degree of parallelism or convergence in these modifications has always been an added difficulty to reveal phylogenetic relationships among the subterranean species [5-8], but at the same time poses a very interesting evolutionary problem, as the mechanisms through which it is achieved remain largely unknown.

According to the traditional view, virtually every species of subterranean Coleoptera developed the troglomorphic characters independently, but recent work on the Pyrenean fauna has challenged this assumption by demonstrating a single origin for ancient and diverse clades of exclusively subterranean species $[9,10]$. At the same time, the phylogeny of Pyrenean Trechini shows
C Biomed Central

(c) 2013 Faille et al.; licensee BioMed Central Ltd. This is an open access article distributed under the terms of the Creative Commons Attribution License (http://creativecommons.org/licenses/by/2.0), which permits unrestricted use, distribution, and reproduction in any medium, provided the original work is properly cited. 
that the currently recognised genera (Aphaenops (nomen protectum [11]), Hydraphaenops and Geotrechus), which were recognised mainly based on strong similarities in the general body shape $[9,10,12]$, are largely poly- or paraphyletic, with a striking degree of morphological convergence.

In a wider study, Faille et al. [13] included other highly modified western Mediterranean cave Trechini considered by some authors to be related to the Pyrenean fauna (i.e. to be members of the "phyletic lineage" of Aphaenops in the sense of Jeannel [2]), such as the Iberian Apoduvalius and Paraphaenops, Speotrechus from southeastern France, or the Sardinian Sardaphaenops. All these species were found to be not related to the Pyrenean fauna but to other lineages in the same geographical areas, showing again a strong morphological convergence among them [13]. However, in that study the basal relationships among the main lineages of the western Mediterranean fauna of Trechini could not be established, likely due to the lack of representation of more eastern lineages.

Here we extend the study of subterranean Trechini to the fauna of the Alps, which include members of the Aphaenops lineage assumed to be related to the Pyrenean fauna but also members of the traditionally recognised second major division of Trechini, the "isotopics" (in opposition to the "anisotopics", which include all the species of the Aphaenops lineage). These two divisions refer to morphological characters of the male genitalia (see below). The fauna of the Alps is extremely rich in both epigean (i.e., living "above ground", in the surface) and hypogean (i.e. living "below ground") Carabidae, with more than 650 species in the eastern part -approximately half of the Italian ground beetle fauna, and a fifth of all European species, from the Canary Islands to the Urals. This area includes more than 200 endemic species, most of them concentrated on the eastern preAlpine belt (the "Southern Alps", from the Como lake to Trieste) and many of them subterranean [14]. It is considered a hotspot of subterranean biodiversity, comparable to the Dinaric Alps or the Pyrenean chain [15]. The easternmost area of the Alps (the "Suprapannonian sector"sensu Ozenda \& Borel [16], around Graz) lacks limestone formations and is less rich in subterranean species (Additional file 1: Figure S1). Similarly, the western part of the chain, from the Lepontine to the MaritimeLigurian Alps, is poor in subterranean species due to the scarcity of limestone in the area north of Torino [17], despite having a very diverse fauna, with 440 species of Carabidae and a high number - c. $30 \%$ - of endemics [18]. Only the Ligurian Alps are entirely calcareous and markedly karstified, with deep and large subterranean systems even at high altitude [19] (Additional file 1: Figure S1).
The Trechini fauna of the Alpine range is one of the best known in the world due to two centuries of studies by professional and amateur speleologists and biospeleologists. The subterranean species are currently grouped into 14 genera, 13 of them endemic to the Alps [11,20-22]. The origin of this subterranean fauna has been debated at length by different authors, who proposed contrasting hypotheses $[2,14,18-20]$. Some of the most specialised and emblematic species have been related to the Pyrenean fauna due to their strikingly similar external appearance, in particular some ultra-specialized Trechini very similar to the Pyrenean Aphaenops (the so called "aphaenopsian" shape $[1,23])$. Within the Alps, some genera have fragmented distributions, such as Duvalius or Trichaphaenops, or morphologically similar genera occupy isolated areas, such as Boldoriella and Orotrechus, and yet some others have divergent morphologies with unknown affinities, such as Doderotrechus, Italaphaenops, Allegrettia or Lessinodytes [14,18-20,24-27]. With this study we attempt to clarify the geographical and temporal origin of all these subterranean taxa with the use of molecular data and a comprehensive representation of the subterranean and epigean European Trechini, including a wide sample of the most diverse and widespread genera (Trechus and Duvalius) as well as examples of all Alpine troglobiont genera but two. Using c. $4 \mathrm{~Kb}$ of a combination of mitochondrial and nuclear markers of 207 specimens in 173 species we use maximum likelihood and Bayesian methods to build a calibrated phylogeny to estimate the temporal origin and the relationships of the subterranean taxa, with a special interest in the most morphologically deviant species, showing the highest degree of troglomorphism and the most enigmatic origin.

\section{Taxonomic background of the Alpine Trechini}

Trechini is a highly diverse and cosmopolitan tribe of carabid beetles, divided in well characterised subtribes [22] (see [28] for an overview of the phylogenetic placement of Trechini). All subterranean European species, together with their related epigean groups, belong to subtribe Trechina, which are traditionally divided into two groups of genera on the basis of differences in the male genitalia. Thus, in the isotopics the endophallus has a symmetric copulatory piece in ventral position ("série phylétique de Duvalius" sensu Jeannel, 1928 [2]), while in the anisotopics the copulatory piece is asymmetric and placed in lateral position (Additional file 2: Figure S2) [6].

There are nine anisotopic and eight isotopic genera of Trechina in the Alpine chain (see Additional file 3: Table S1 for a list of genera, their distribution and number of species, and the number of specimens included in our analyses). Seven of the anisotopic genera are found in the southeastern part of the chain, from the Como Lake 


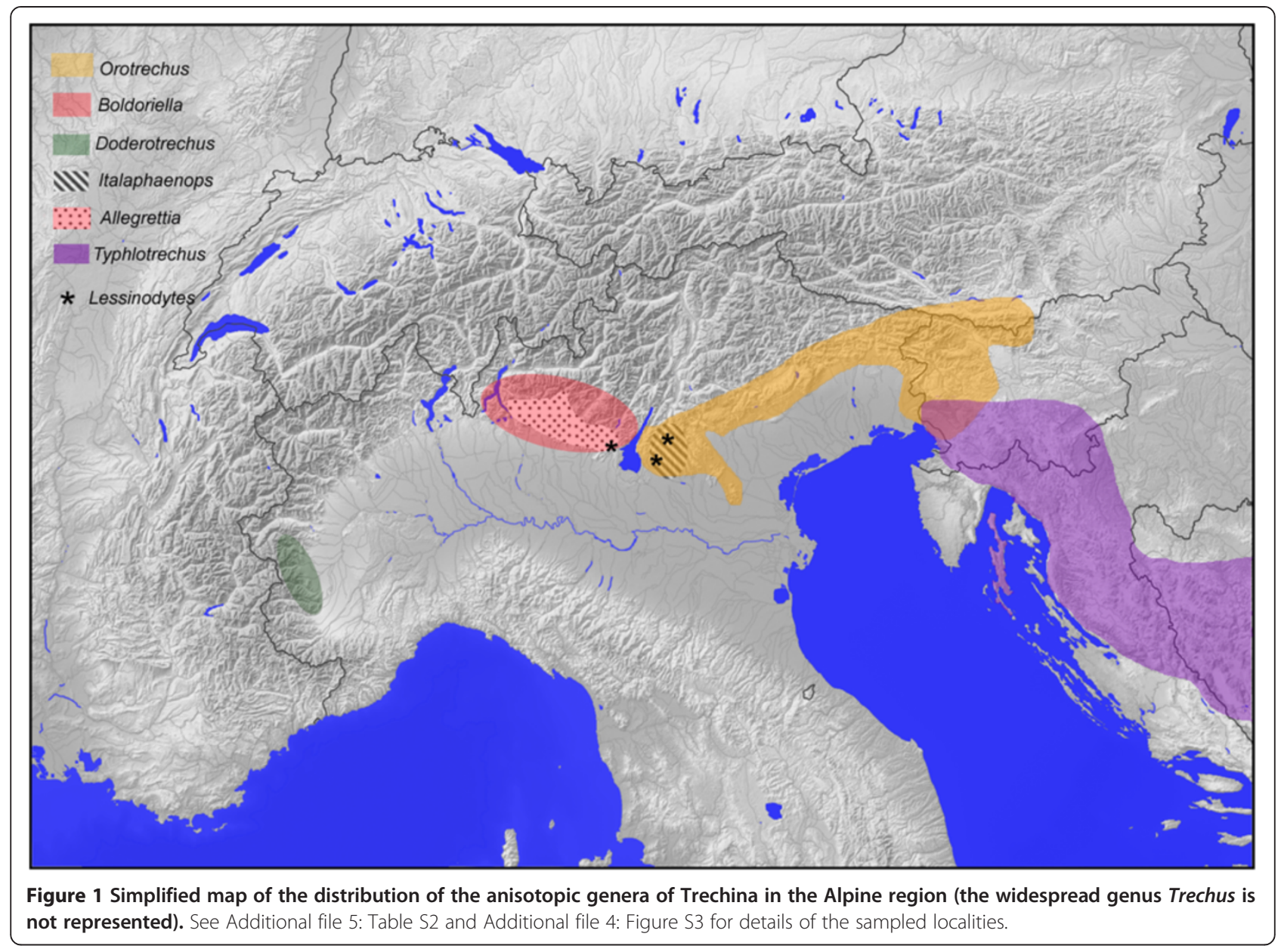

(Lombardy, Italy) to Trieste and Slovenia (Figure 1). The only exceptions are Doderotrechus, an endemic to the Cottian Alps in the Italian Piedmont living in natural limestone caves, artificial mines and the MSS ("millieu souterrain superficiel", or mesovoid shallow substratum), and the diverse, widespread and mostly epigean genus Trechus. Trechus has more than 800 species, mostly in the Palearctic region [12,22], and includes widespread winged species as well as short-range wingless endemics, many of them restricted to individual mountain massifs [29-31]. There are many species with different degrees of troglomorphism. Faille et al. $[9,13]$ shown that the genus is a paraphyletic assemblage with some troglobitic genera or species nested within it. In the Alpine chain there are no species of Trechus exclusive of the subterranean environment, although some species are regularly found in it, and some high altitude orophilous species (e.g. in the T. strigipennis group) show depigmentation and reduced eyes.

Seven of the eight isotopic genera of Trechina present in the Alps are subterranean and endemic to this area (Additional file 3: Table S1). Only one of them, Duvalius, has a wider distribution (Figure 2). The ecological preferences and degree of troglomorphism of the members of the speciose genus Duvalius are very diverse: some are depigmented and blind, hygrophilous, nivicolous and living in caves, deep soil or MSS; but others are epigean, living in forest litter and alpine pastures, and are slightly pigmented and/or with reduced eyes, and even (albeit exceptionally) winged [32]. The genus is widely distributed from Spain, Maghreb (Algeria) and France in the West to central Asia and China in the East. It is diversified mostly in the Alps, Italian and Balkan peninsulas and the Carpathian region, with some species in Catalonia, Mallorca, Sicily and Sardinia. Easter of the Alps the genus is recorded from the Caucasus, Middle East and Iran, reaching the Tien Shan Mountains in China [12]. The Alpine species belong to the subgenus Duvalius and have been divided into various species groups ( 14 for the Italian species [20]), which in turn have been divided in more numerous "lineages" [33,34], mostly based on the structure of the copulatory piece. The genus was considered as a complex by Jeannel [23], with more troglomorphic genera derived from local species pools. 


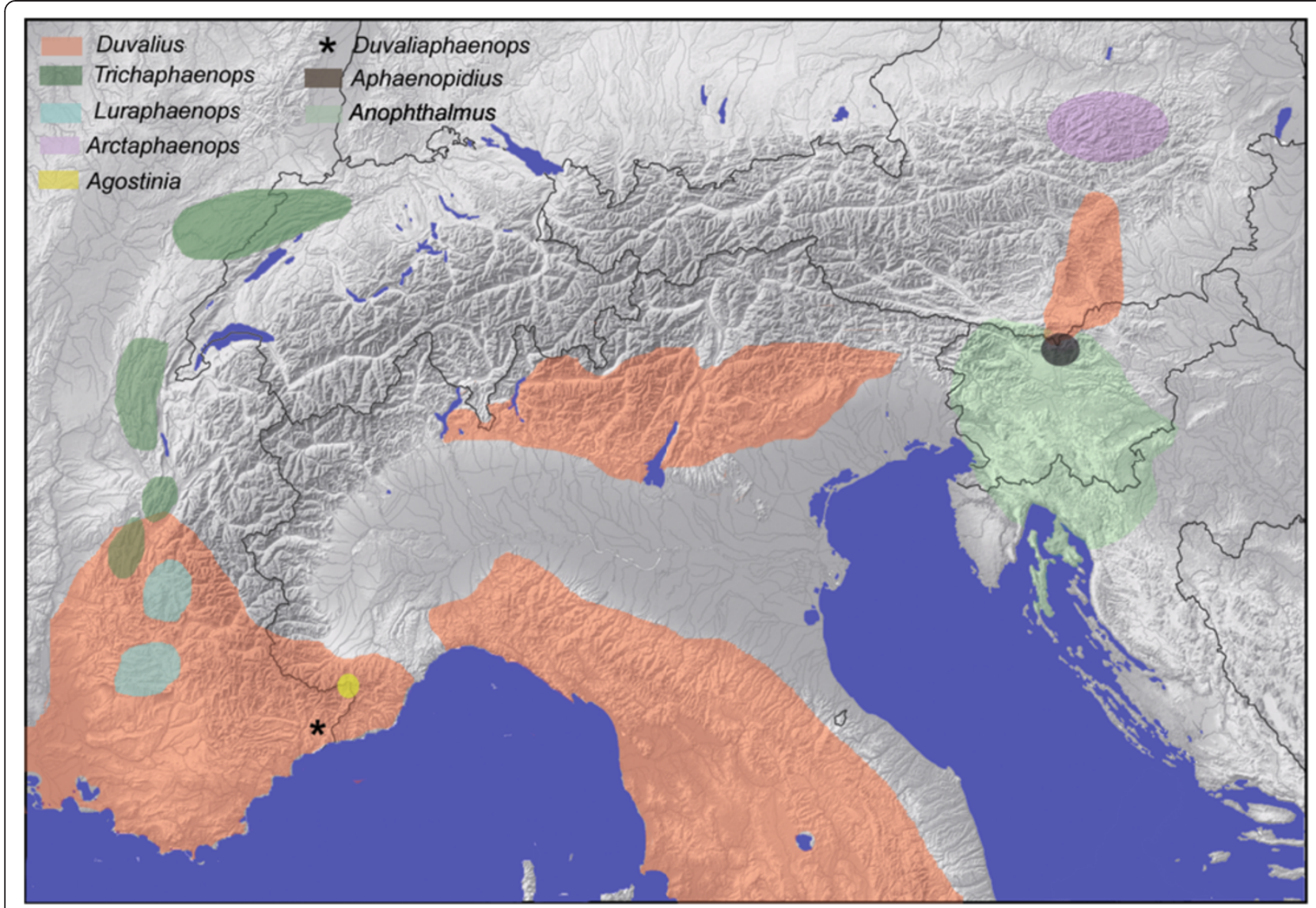

Figure 2 Simplified map of the distribution of the isotopic genera of Trechina in the Alpine region. See Additional file 5: Table S2 and Additional file 4: Figure S3 for details of the sampled localities.

\section{Other subterranean Trechini potentially related to the Alpine fauna}

We included in our study three species of the two anisotopic genera Neotrechus and Adriaphaenops from the Dinaric Alps, to test for potential relationships with the species of the Alpine fauna. The Dinaric karst is a recognised hotspot of subterranean biodiversity [35] especially rich in highly specialised troglomorphic Trechini, with new genera and species described every year (see e.g. $[36,37])$. The phylogenetic relationships of this highly diverse trechine fauna are unknown, but the two genera included here have been related to Alpine or Pyrenean taxa: Neotrechus is currently considered as close to the Alpine genus Orotrechus, whereas Adriaphaenops was considered a representative of the former Aphaenops lineage. Nevertheless, recent molecular results cast doubts on the possibility of such relationships $[9,38]$. We also include an example of Pheggomisetes (with three described species), known from some caves in the Bulgarian and Serbian Balkans and with a highly derived morphology. It was considered as an isolated relict of the Eocene fauna, without clear affinities with the extant Trechini [2].

\section{Results}

\section{Phylogenetic analysis}

The estimated optimal evolutionary model was GTR + I + $\mathrm{G}$ for the three mitochondrial gene partitions (cox1, $r r n L+$ $\operatorname{trnL}$ and $n a d 1$ ) and the nuclear small ribosomal unit $(S S U)$, and GTR + G for the nuclear large ribosomal unit $(L S U)$. In each of two independent MrBayes analyses the two runs (i.e. a total of four runs) reached convergence after 34 MY generations as measured with the effective sample size (ESS). The combination of the four runs also converged for most of the parameters (including the total likelihood of the trees), but had two alternative states (with two runs each) differing substantially in some parameters that did not converge, such as e.g. the total branch length, double in one state than in the other, or the alpha parameter of the gamma distribution in all partitions except the nuclear $L S U$. Despite the large differences in some of the parameters the two topologies were congruent for all well supported nodes (Figure 3). The topology obtained with Maximum Likelihood in RAxML was also generally congruent with the MrBayes trees, with only some poorly supported 


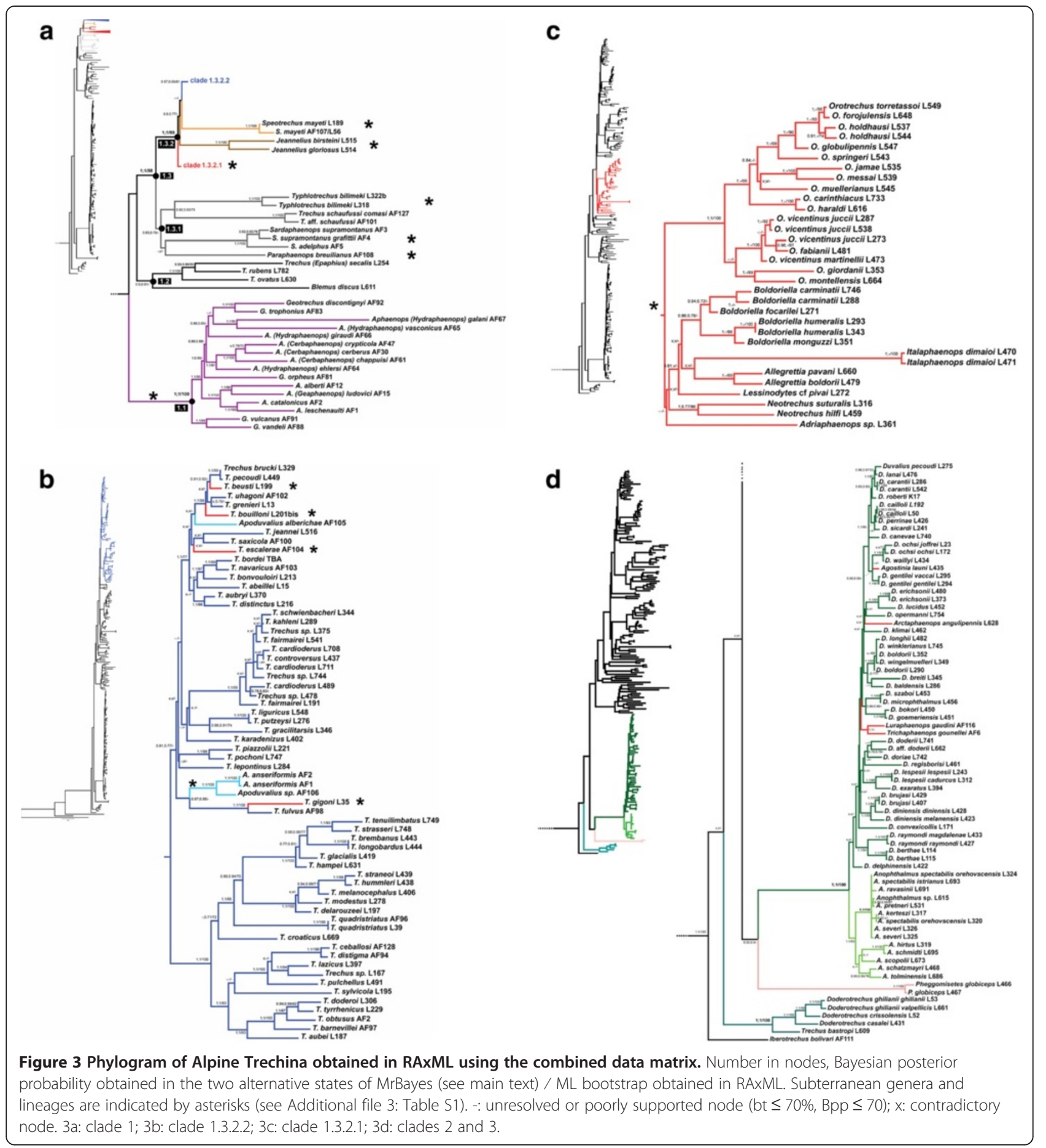

nodes showing incongruence (Figure 3) (see detailed comments below).

In all cases the monophyly of Trechina was strongly supported, with three main clades that were recovered in all analyses. Clade 1 (Figures $3 \mathrm{a}-\mathrm{c}$ and 4 ) included most of the anisotopic species: the Pyrenean hypogean lineage (clade 1.1, Figures 3a and 4), the genus Epaphius and relatives (Blemus and some species of Trechus, clade 1.2) and a large group including most species of the genus Trechus plus a number of subterranean genera nested within it (clade 1.3). These included all the Alpine and Dinaric subterranean anisotopic genera with the only exception of Doderotrechus, plus some other genera from nearby areas (Speotrechus, Jeannelius, Typhlotrechus, Sardaphaenops and Paraphaenops, Figures 1 and 3). 


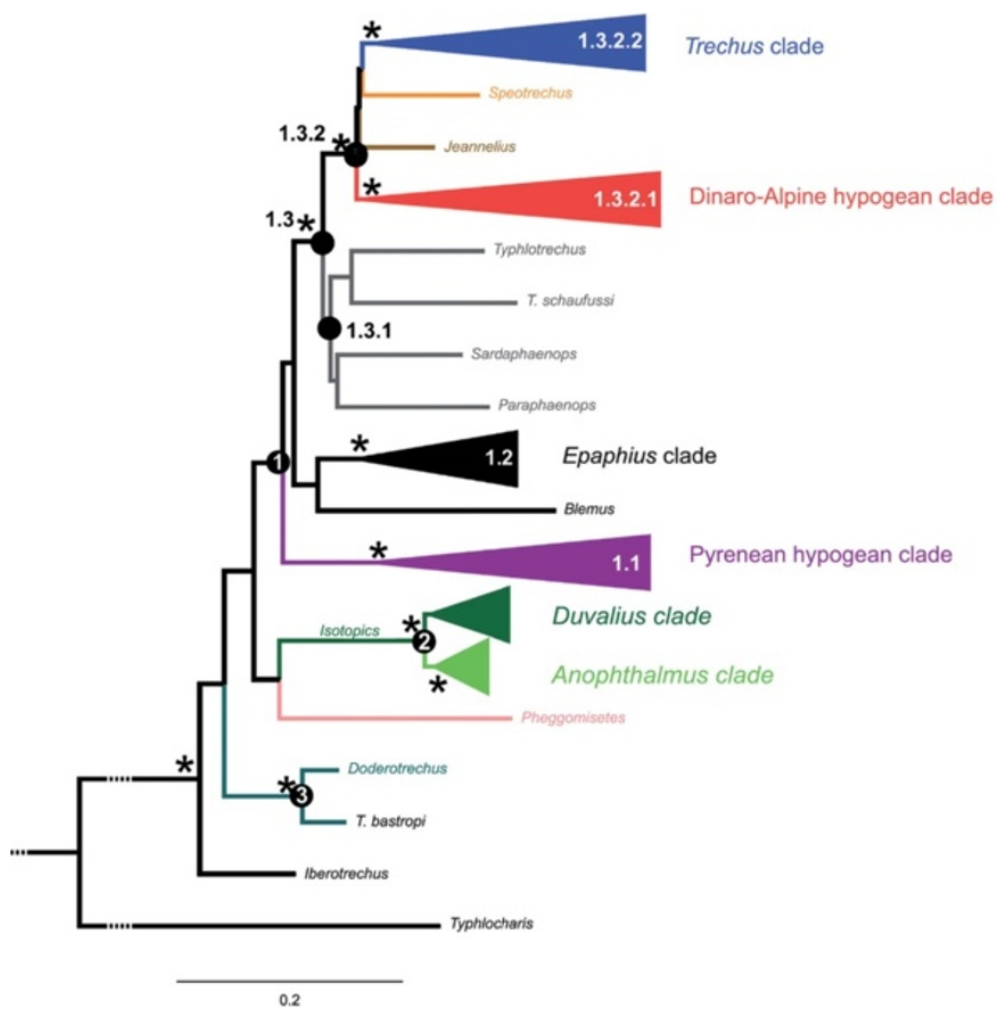

Figure 4 Summary tree with the main clades of Alpine Trechini, as obtained with RAxML. Stars, nodes with a support of $p p=1$ for both Bayesian topologies and bt $=100$ for RAxML. -, unresolved or poorly supported node (bt $\leq 70 \%, \mathrm{Bpp} \leq 70$ ); $x$, node not present. Node labels refer to major clades (see text and Figure 3); For each of the clades the number of genera and species included in the analyses is given in brackets.

Clade 2 (Figures 3d and 4), well-supported in all analyses (Bayesian posterior probability, $\mathrm{pp}=1$; ML bootstrap support, bt $=100$ ), included all the isotopic species, with a largely paraphyletic Duvalius and the five subterranean genera (Anophthalmus, Arctaphaenops, Agostinia, Luraphaenops and Trichaphaenops) nested within it in uncertain positions. The Balkan genus Pheggomisetes was found sister to this clade 2, although with only moderated support ( $\mathrm{pp}=0.92 / 0.89$; $\mathrm{bt}=52)$. Clade 3 , also well-supported ( $\mathrm{pp}=1$; bt $=100)$ (Figures $3 \mathrm{~d}$ and 4$)$, included the remaining anisotopics: the Alpine genus Doderotrechus plus a species of Trechus from Tibet, $T$. bastropi. The isolated genus Iberotrechus was in some analyses recovered as sister to this clade, with low support.

\section{Clade 1.1, the Pyrenean hypogean lineage}

In agreement with previously published phylogenies [9,13], none of the three Pyrenean genera Aphaenops, Geotrechus and Hydraphaenops were recovered as monophyletic. The Pyrenean lineage was sister to the rest of clade 1 in all reconstructions, but this sister relationship was not well supported (Figures 3a and 4).

\section{Clade 1.2, the "Epaphius" group}

Epaphius and two species of Trechus, one widespread (T. rubens) and an Alpine endemic ( $T$. ovatus), were grouped in a well-supported clade $(\mathrm{pp}=1 ; \mathrm{bt}=100)$. We found the genus Blemus sister of this clade, although supported only in the Bayesian analyses ( $\mathrm{pp}=0.9$; bt $<50$ ).

\section{Clade 1.3, Trechus and other hypogean anisotopics}

This well-supported clade $(\mathrm{pp}=1$; bt $=88)$ was subdivided into two groups, the first (1.3.1) with CircumMediterranean species, gathering two Iberian Trechus with the highly modified genera Sardaphaenops (Sardinia), Paraphaenops (Iberia) and the Adriatic Typhlotrechus. This group was not well supported, although it was recovered both in the ML (bt $<50)$ and the Bayesian analyses $(\mathrm{pp}=0.83 / 0.79)$. The second main group (1.3.2) was very well-supported $(\mathrm{pp}=1 ; \mathrm{bt}=99)$ and included the Caucasian endemic genus Jeannelius, the French hypogean genus Speotrechus, a clade (1.3.2.1) with all the hypogean genera of anisotopic Trechina from the Alps (except Doderotrechus) plus the Dinaric hypogean genera, and a clade (1.3.2.2) with most of the Trechus species including many Alpine endemics and the type species of the genus, T. quadristriatus. 
The clade 1.3.2.1 was well-supported $(\mathrm{bt}=80 ; \mathrm{pp}=0.99 / 1$ ) and included the subterranean genera Orotrechus, Boldoriella, Lessinodytes, Allegrettia, Italaphaenops and the two Dinaric genera Adriaphaenops and Neotrechus (Figure 3c). No epigean species were nested within this clade. The monophyly of both genera Orotrechus and Boldoriella was confirmed, whereas the position of Lessinodytes, Allegrettia and Italaphaenops, as well as that of the Dinaric species, was uncertain. A sister relationship was suggested in the ML analysis between Allegrettia and Italaphaenops, but without support and not recovered in the Bayesian analyses.

The sampled species of the genus Orotrechus were recovered as monophyletic, and divided in two groups of species: the first, poorly supported $(\mathrm{pp}=0.54 / 0.97$; bt $=66$ ) including $O$. vicentinus, O. fabianii, O. giordanii and $O$. montellensis, and the second, well-supported ( $\mathrm{pp}=1$; bt $=99$ ), with all other sampled species (Figure 3c). The two aphaenopsian species $O$. jamae and O. messai, currently attributed to different species groups [20], were included in the same clade. The genus Boldoriella was found monophyletic with low support $(\mathrm{pp}=0.86 / 0.92$; bt $=54$ ), but the separation of two subgenera within Boldoriella (Boldoriella and Insubrites [26]) was not supported by our analyses, as B. (Insubrites) focarilei was closer to $B$. (Boldoriella) carminatii than to B. (Boldoriella) humeralis.

The clade 1.3.2.2 was also well-supported ( $\mathrm{pp}=0.97$ / 0.99 ; bt $=81$ ), and included most of the species of Trechus sensu stricto (including the type species of the genus). Seven sub-clades were recovered with general good support, together with some isolated species of uncertain position (T. karadenizus and T. lepontinus, Figure 3b): (1) a Pyrenean-Cantabrian clade ( $\mathrm{pp}=1$; bt $=77$ ), which included 16 species, some of them hypogean (T. beusti, T. navaricus, T. bouilloni, T. escalerae and Apoduvalius alberichae); (2) the group of $T$. fairmairei and closely related species; (3) two species of the Maritime and Ligurian Alps, T. liguricus and T. putzeysi, as sister (with low support) to a species from the Eastern Alps, T. gracilitarsis; (4) the two species of the T. strigipennis species group as currently defined [14,39] (T. pochoni and T. piazzolii); (5) two species of Apoduvalius, with uncertain affinities; (6) the Trechus fulvus group, here represented by the species $T$. fulvus and $T$. gigoni (the latter described as Antoinella [40]); and (7) a clade containing $T$. quadristriatus and T.obtusus, plus some Alpine and Pyrenean endemics as well as species from Turkey.

\section{Clade 2, the isotopic Trechina}

The isotopic Trechina in the traditional sense $[2,30]$ were confirmed as monophyletic with strong support $(\mathrm{pp}=1 ; \mathrm{bt}=100)$, although the internal resolution was poor. The genus Anophthalmus was recovered as monophyletic $(\mathrm{pp}=1 ; \mathrm{bt}=100)$, but depending on the phylogenetic method used it was sister to the rest of Duvalius species plus the subterranean genera Agostinia, Trichaphaenops, and Arctaphaenops (ML), or nested within this group (Bayesian), in both cases with low support (Figures 3d and 4). In all cases the rest of the subterranean isotopic genera were nested within a largely paraphyletic Duvalius. Some of the supported lineages had a well defined geographical distribution, such as a clade of species from the Maritime and Ligurian Alps, including the subterranean Agostinia launi plus the Duvalius carantii, canevai, clairi and gentilei species groups (sensu Vigna Taglianti [20]) (although with good support only in the Bayesian analyses, $\mathrm{pp}=1 / 0.98$; bt $=56$ ); or $D$. berthae from Catalonia, unambiguously related to $D$. raymondi from Provence (Southern France) $(\mathrm{pp}=1 ; \mathrm{bt}=94)$. Some other lineages corresponded to species groups defined on the basis of morphology, such as the subgenus Euduvalius, the D. longhii (pars) and D. baldensis groups sensu Vigna Taglianti [20], or the $D$. microphthalmus group sensu Jeannel [2].

\section{Clade 3, Doderotrechus}

The phylogenetic position of the genus Doderotrechus within Trechina was not well supported, although the Bayesian analyses suggested a closer relationship to the isotopics than to the main clade of anisotopics (Figures 3d and 4). Doderotrechus casalei, which was considered close to D. crissolensis [41], was recovered as sister to the rest of the species. The genus was found to be sister to a Himalayan Trechus recently described from southcentral Tibet, T. bastropi, with strong support $(\mathrm{pp}=1$; bt $=100)$.

\section{Estimation of divergence dates}

According to our results, based on the rates estimated for a related ground beetle genus using the same genes [42], the origin of the Trechina radiation dates back to the middle Eocene (Figure 5). The origin of the main lineages within Trechina dates back to the late Eoceneearly Oligocene, although the last common ancestor of the sampled species of some of them was estimated to be of much more recent origin, in the Miocene. Thus, the origin of the Pyrenean lineage was estimated to be at the end of Eocene, but the present-day species diversified from the early Miocene (c. $23 \mathrm{Ma}$, Figure 5). Similarly, the isotopic clade (clade 2) separated from the basal Trechina in the upper Oligocene, but the diversification of the group was estimated to be at the late Miocene, c. $10 \mathrm{Ma}$, in a rapid succession. Some of the subterranean clades (e.g. Luraphaenops + Trichaphaenops or Anophthalmus) originated short after the origin of the diversification of the clade, whereas the two other genera (Arctaphaenops and Agostinia) originated later, in the Lower Pliocene. The estimated age of the isolation between the 


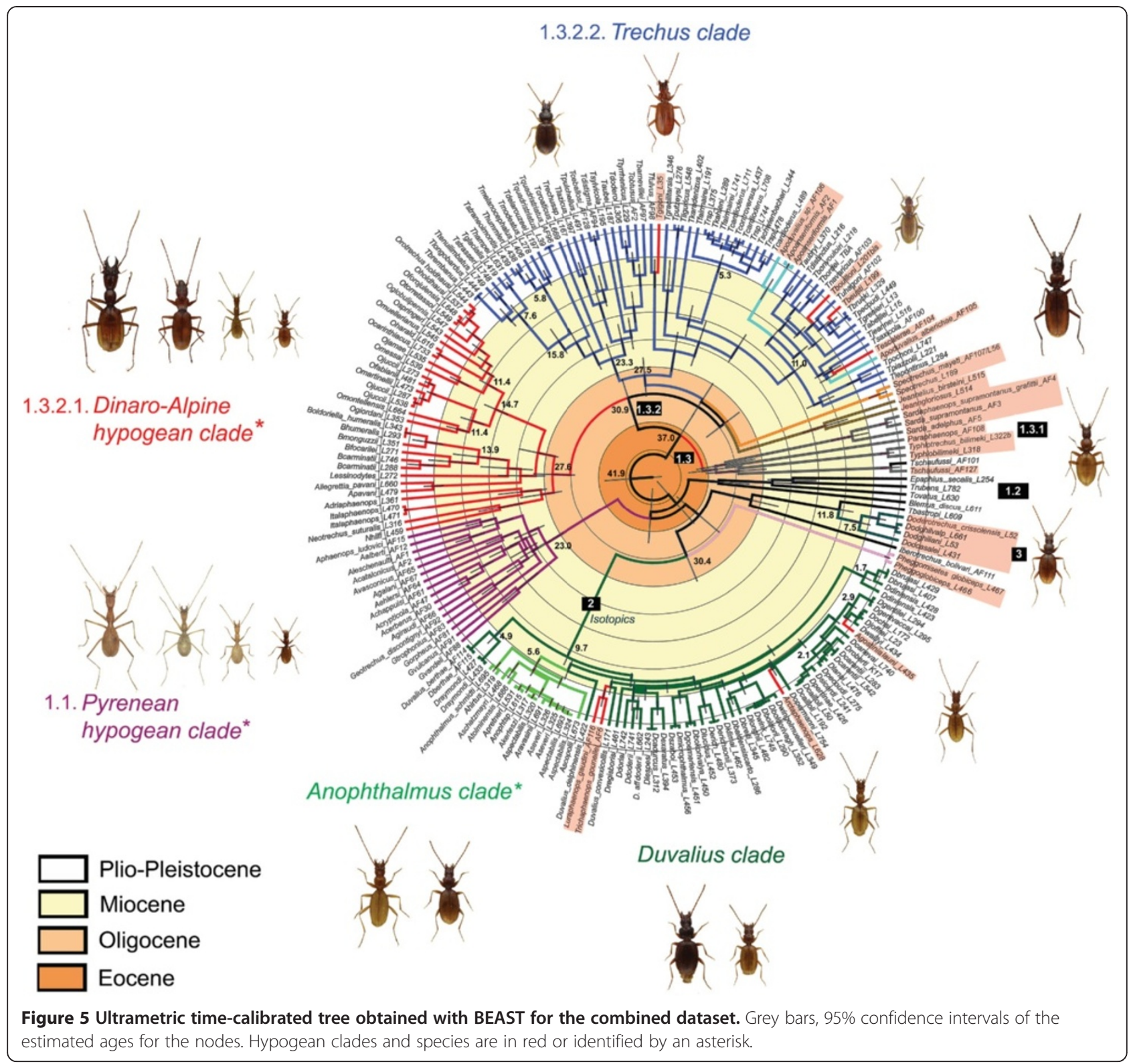

only Iberian species, $D$. berthae, and the French $D$. raymondi was estimated to be at the end of the Miocene.

Other lineages had an earlier diversification, as estimated from our results. The hypogean Dinaric-Alpine clade (clade 1.3.2.1, Figure $3 \mathrm{~b}$ ) diversified in the late Oligocene, with an early isolation of the Dinaric species plus Italaphaenops from the other Alpine genera (although the phylogenetic position of Italaphaenops was not well supported, see above). The origin of the radiation including all the subterranean anisotopic genera but Italaphaenops was contemporaneous with that of the Pyrenean clade, in the early Miocene. Similarly, the diversification of the main clade of Trechus (clade 1.3.2.2) was also dated in the late Oligocene. Most of the subterranean colonisations within the Trechus lineage were also estimated to have occurred during the middle and late Miocene, as well as the separation between the Himalayan Trechus bastropi and the hypogean genus Doderotrechus. On the contrary, the subterranean genera Sardaphaenops, Paraphaenops, Typhlotrechus, Speotrechus and Jeannelius were estimated to be of Oligocene origin (Figure 5). The estimated age of the origin of the Sardinian endemic Sardaphaenops was 33 Ma.

\section{Discussion}

\section{Phylogeny of the Alpine Trechina}

In agreement with previous phylogenetic analyses $[13,28,43]$ we found strong support for the monophyly of the subtribe Trechina, although the phylogenetic relationships among the main lineages of this subtribe remain uncertain. Contrary to the Pyrenean lineage, the 
Trechina of the Alps do not form a geographically welldefined unit, even when the widespread genera Trechus and Duvalius are not considered. Some genera of subterranean blind Trechini of the Dinarides (Adriaphaenops and Neotrechus, the two included in our study) were nested within the lineage of subterranean anisotopic Trechini from the Alps (our clade 1.3.2.1), stressing the need to include more Dinaric genera to establish the phylogenetic relationships of the group and understanding its origin and the colonisation of the area by subterranean Trechini. Recent discoveries of unexpected and remarkable genera in the Dinaric karst suggest that the subterranean fauna of this area needs further investigation [36-38].

Our age estimations were based on rates obtained in [42] for a related genus of groundbeetle using a combination of fossil and biogeograhic events (see Methods below), but were remarkably similar to those obtained by a previous work on western Mediterranean Trechini using as a calibration point the vicariant separation of the genus Sardaphaenops due to the tectonic drift of the Sardinian plate from the continent ca. $33 \mathrm{Ma}$ [13]. Thus, even when the tectonic separation of Sardinia was not used as a calibration point in [42], our estimate for the origin of Sardaphaenops was 32.7 Ma, fully in agreement with a vicariant tectonic origin. Similarly, the estimated ages of e.g. the Pyrenean, Duvalius sensu lato, main group of Trechus and Doderotrechus + Iberotrechus crown clades were respectively 22.7, 9.6, 24.8 and 23.4 Ma in [13], versus 23.0, 9.7, 27.5 and 27.8 Ma here.

\section{The anisotopic genera}

Our results confirm the monophyly of the Pyrenean lineage [9], as none of the hypogean highly modified Trechini of the Alps and Dinaric chains were found to be related to it. The Pyrenean hypogean lineage remains isolated, with no clear affinities with other Trechini, and the similarities in the body shape of the species included in the Aphaenops lineage of Jeannel [2] should thus be the result of convergence or parallelism (see below). We also found support for the monophyly of the genus Orotrechus, characterised by the presence of a peculiar, synapomorphic structure of the lamellar parameres in the male genitalia and by having only the first tarsomere dilated in the male. These well defined morphological synapomorphies prevented authors from describing species with an aphaenopsian and non-aphaenopsian general body shape as different genera [2], as it happened in other cases. Thus, in the same genus it is possible to find all degrees of troglomorphism, from the small-sized, poorly specialised endogean species (such as O. mandriolae (Ganglbauer) or O. cavallensis Jeannel), to the anophthalmous hypogean species (such as O. holdhausi (Ganglbauer)) and finally the highly modified aphaenopsid species (such as O. venetianus
(Winkler), O. stephani (J. Müller), O. jamae, O. theresiae Casale, Etonti \& Giachino, O. gigas Vigna Taglianti and others). Our preliminary results suggest a complex history of the genus, with various species groups colonizing the same area at different times (e.g. several sympatric species with different degrees of troglomorphism are known in the Cansiglio-Cavallo massif in the Eastern Italian Alps [14]), as observed in the Trechus lineage. Although our sampling only included less than half of the described species, it is apparent that the genus needs a taxonomic revision, as none of the species groups previously suggested was found to be monophyletic $[2,20,30,44,45]$. We did not find, however, evidence for the assumed close relationship between this genus and Neotrechus (the "Neotrechus lineage" of Jeannel [2], accepted by all subsequent authors), although the lack of support does not allow to completely discard this hypothesis.

We also did not found a close relationship between the highly modified subterranean genera Allegrettia, from the Italian Alps, and Jeannelius, from the Caucasus, as hypothesized by some authors due to their strikingly similar external morphology $[27,46,47]$. The inclusion of other Caucasian genera will allow to test the alternative hypothesis of Jeannel [48], who suggested that Jeannelius is more related to other Caucasian genera than to the Italian Allegrettia.

An unexpected relationship was that of the westernAlpine genus Doderotrechus with a Himalayan Trechus from south-central Tibet. Trechus bastropi belongs to a group of species (the $T$. dacatraianus group) considered to be isolated within the Himalayan Trechus fauna owing to the structure of the male genitalia [31]. Such affinities were unexpected but not unique: in the western Alps there is a very isolated endemic subterranean species of Sphodrina ground beetle, Sphodropsis ghilianii (Schaum), the type species and only Alpine representative of a genus that includes several Asiatic species [49]. Furthermore, the presence in the Alps of other species of ground beetles considered to be relicts, belonging to genera mainly diversified in Asia (e.g. Broscosoma Rosenhauer [14]), is well known.

\section{The isotopic genera}

We found support for the monophyly of the isotopics, as a derived lineage nested within the anisotopics. Although the dichotomy isotopics-anisotopics is usually applied only to the species of Trechina [6], the asymmetry of the endophallus is a character present in all species of Trechini, and thus can be assumed to be plesiomorphic. According to our results, the diversification of the Duvalius clade occurred later than that of most of the anisotopics lineages, but was more geographically widespread and species rich than most of them. The possible relationship of the symmetry of the male 
genitalia with an increased diversification and geographical expansion seems difficult to explain from an evolutionary point of view, and due to its unique character it also cannot be statistically tested. The detailed study of the diversification of the isotopic lineage would require a more complete sampling of the high number of species of Duvalius from other geographical areas, from the Iberian peninsula and the Maghreb to central Asia. Similarly, the incomplete sampling of the species of Anophthalmus did not allow us to unambiguously solve if Duvalius (in its widest sense) is monophyletic and sister to it, or if Anophthalmus is a lineage nested within Duvalius, as previously hypothesized [2]. The sister relationship between Anophthalmus and the French Duvalius delphinensis, even if poorly supported and present only with Bayesian methods, is intriguing as this is considered to be an isolated species within Duvalius, but with some morphological characters common with Anophthalmus (shape of the male genitalia, pubescence of the head $[2,23])$. As seen with other genera, Anophthalmus includes species with various degrees of specialisation to the subterranean environment, from endogean or nivicolous to strictly troglobitic. The genus differs from Duvalius mainly in the elytral chaetotaxy [2], and previous attempts to clarify its taxonomy based on morphological characters have not reached a wide consensus (e.g. [50-54]).

The lack of resolution within the Duvalius lineage suggests a rapid diversification, which according to our estimations happened mostly in the late Miocene. The origin of some of the most troglomorphic genera, such as Arctaphaenops, Agostinia, Luraphaenops and Trichaphaenops, with a marked aphaenopsian habitus, was estimated to be Plio- or Pleistocene, more recent than that of other similarly modified genera from the area (e.g. Italaphaenops or Lessinodytes, from the early Miocene). The detailed phylogenetic affinities of these genera are still uncertain, although some of our results contradict assumed relationships. Thus, Agostinia launi appears to be closer to Duvalius ochsi and D. gentilei than to $D$. carantii, contrary to previous hypotheses $[2,20]$. Trichaphaenops and Luraphaenops were found to be sister taxa, suggesting a common origin of the morphological modifications of the two genera, but it would be necessary to study species of Duvaliaphaenops to further confirm this hypothesis. In all these cases the subterranean taxa tended to be related with other geographically close lineages, as found in previous works with subterranean Trechini and Leptodirini $[9,10]$. In agreement with this general pattern, our expectation is that the genus Arctaphaenops should also be closer to some Duvalius species of the same geographical area (which could not be included in our study) than to other aphaenopsian isotopic Trechini from the western Alps to which it was traditionally related (Trichaphaenops [6]). The large geographical gap between Arctaphaenops in the northeastern Alps and Trichaphaenops in the southwestern Alps and the Jura was explained by an hypothetical extinction of all intermediate forms by Pleistocene glaciers on the northern side of the Alps [6]. However, the ecology of some Arctaphaenops species, able to live at high altitude in cold, ice caves [55], contributes to weaken this hypothesis of an extinction by glacial episodes, not supported by our phylogeny. The inclusion of some of the northernmost species of Trichaphaenops and the easternmost Duvalius may help to clarify the phylogenetic relationships of Arctaphaenops.

Another example of unexpected affinities between geographically close taxa is that of the species Duvalius raymondi (French Provence) and D. berthae (Catalonia). Duvalius berthae, the only Iberian species of the genus, was thought to be very close to $D$. lespesi [2], from the French Causses. On the contrary, this later species was found to be related to $D$. exaratus, from the Eastern Alps, included in a different species group by Jeannel [2] (the D. longhii group) because it was pigmented and oculated. Vigna Taglianti [20] recognised the morphological peculiarities of $D$. exaratus, considering it an isolated species within the $D$. longhii group. Although not definitely discarded, the hypothesis of possible affinities between Duvalius and Doderotrechus previously suggested [13] was not supported by our results.

\section{Origin of the subterranean lineages of Alpine (and nearby areas) Trechini}

Subterranean Trechini can be considered a good example of abiotically limited relicts [56,57]. Karstic areas, and more generally the deep soil fissures, may act as a buffer zone protecting subterranean animals from rapid and strong fluctuations of hygrometry, allowing the persistence of strict hygrophilous species with very reduced dispersal power outside this environment in the present day climate conditions. Subterranean species are known to be able to colonize all kinds of underground compartments [58-60], but, despite the physiological limitations, some amount of surface dispersal must have also occurred at some time in some taxa with already a high degree of troglomorphism, as shown by recent phylogenetic contributions $[9,12,61]$. The ancient origin of some of the subterranean lineages is in agreement with the age of many alpine caves (excluding paleokarst), which are of Pliocene or even Miocene age, although the karstification of some massifs colonised by hypogean Trechini (e.g. the Vercors massif in southeast France, the Lessini Mountains in northeast Italy, and others) has been more or less continuous since the Eocene [17].

Some of the discontinuities in the current distribution of the subterranean genera may also be explained by the geological history of the area. Thus, the geographical gap 
between the hypogean anisotopic Alpine and Dinaric genera may be explained by marine transgressions that occurred during the middle Miocene north of Zagreb [62], which could have led to the destruction of the fauna of this area and/or promoted the isolation of the ancestors of the extant species. It is interesting to note the presence in this area of the polytypic, enigmatic species Typhlotrechus bilimeki, the phylogenetic position of which was not well supported although our results suggested it may be related to the Iberian species Trechus schaufussi ("groupe pandellei" sensu Jeannel [2]), with an ancient (Oligocene) divergence. By the late middle Miocene the marine transgresion between the Dinarides and the Alps had definitively disappeared, and the ancestors of the isotopic genus Anophthalmus should have colonised the area.

According to our results, and in agreement with previous work of a more limited geographical scope [13], there are multiple origins of the highly modified hypogean Trechini in the western Palaearctic, with a high degree of convergence or parallelism among species occupying the same microenvironment. Both within the hypogean Alpine anisotopic and the Dinaric clades it is possible to recognise the same morphological types found in the Pyrenees $[2,6,9]$. Species occurring mostly in the soil, in superficial fissures or in the mesovoid shallow substratum (MSS), sometimes also nivicolous at high altitude, such as the genera Orotrechus and Boldoriella, have a similar general morphology than the species of Geotrechus in the Pyrenees, more stout and robust and with shorter legs and antennae. Highly hygrophilic, small species living in deep fissures and only exceptionally appearing in accessible caves, such as Lessinodytes, are very similar to the Pyrenean Hydraphaenops, with a narrow pronotum and head, often hairy body and long mandibles. Finally, species living in deep subterranean fissures and in natural or artificial caves (such as some Orotrechus and Boldoriella, Allegrettia and Italaphaenops) share with the Pyrenean Aphaenops an extreme elongation of the body, specially pronotum, head and appendages, leading to the typical "aphaenopsian" facies. It must be stressed that all three Pyrenean genera are para- or polyphyletic, increasing considerably the number of independent developments of each of the characteristic morphotypes [9].

As noted above, in many cases the highly modified subterranean species can be related to other epigean (or less modified) taxa in the same geographical area, such as for example the species of the genera Apoduvalius and Antoinella (the latter already proposed as a synonym of Trechus, related to the species of the fulvus group [63]), which are confirmed as polyphyletic and to belong to the Trechus lineage. In the case of the $T$. fulvus group, it seems likely that from an epigean, widespread species ( $T$. fulvus) there were many instances of independent populations colonising the subterranean environment (as schematised in Figure 6a), some of them recognised as distinct species but others only as subspecies or simple varieties, and most of them -but not all- wingless and with different degree of eye reduction [64]. This seems also to be the case of the widespread genus Duvalius, nested within which there are some highly troglomorphic species currently considered as distinct genera (Arctaphaenops, Agostinia, Trichaphaenops and Luraphaenops). In the Duvalius lineage, and contrary to what happens with the T. fulvus group, the origin of the highly troglomorphic taxa cannot be directly traced to a single, widespread species, so there is the possibility that the colonisation of the subterranean environment was preceded by local speciation of still epigean species (Figure 6b).

It is, however, remarkable that some monophyletic and exclusively subterranean lineages, without recent epigean relatives, are of ancient origin and include a high number of taxa in a relatively large geographical area, such as e.g. the Pyrenean lineage (clade 1.1 in Figure 4), the Dinaric-Alpine hypogean clade (clade 1.3.2.1) or the genus Anophthalmus. For these lineages, the most parsimonious scenario is a single origin of the subterranean habit and the associated troglomorphic characters (Figure 6c). This would imply the possibility that highly modified species were able to expand their geographical ranges and diversify, in some instances necessarily requiring surface displacements. This arguably happened in the highly modified Leptodirini genus Troglocharinus from the Pyrenees, which colonised the coastal area south of Barcelona during a climatically favourable time window in the early Pliocene [61]. In the case of the DinaricAlpine subterranean clade (1.3.2.1), which includes taxa from the Dinarides and the southeastern Italian Alps (i.e. the "Illyrian-Gardesan Dolomitic sector" sensu Ozenda \& Borel [16]), the almost continuous presence of karst through this area (Additional file 1: Figure S1) may have allowed the displacement of species not able to leave the subterranean environment. The absence of subterranean anisotopic species in the northeastern calcareous Alps (Figure 1), in where there is only an isotopic subterranean genus of Trechini (Arctaphaenops, of a much more recent origin), would be in agreement with this hypothesis. Thus, it seems that no anisotopic taxa of this clade was able to cross the Suprapannonian sector [16,65], without karst in a large area around Graz (Additional file 1: Figure S1), suggesting that they were not able to disperse long distances outside the subterranean environment. It is always possible that the geographic expansion of this clade was due to epigean ancestors which are now all extinct or remain unknown, and that the troglomorphic species have thus an independent, local origin. However, at present there is no evidence to support this hypothesis, which on 


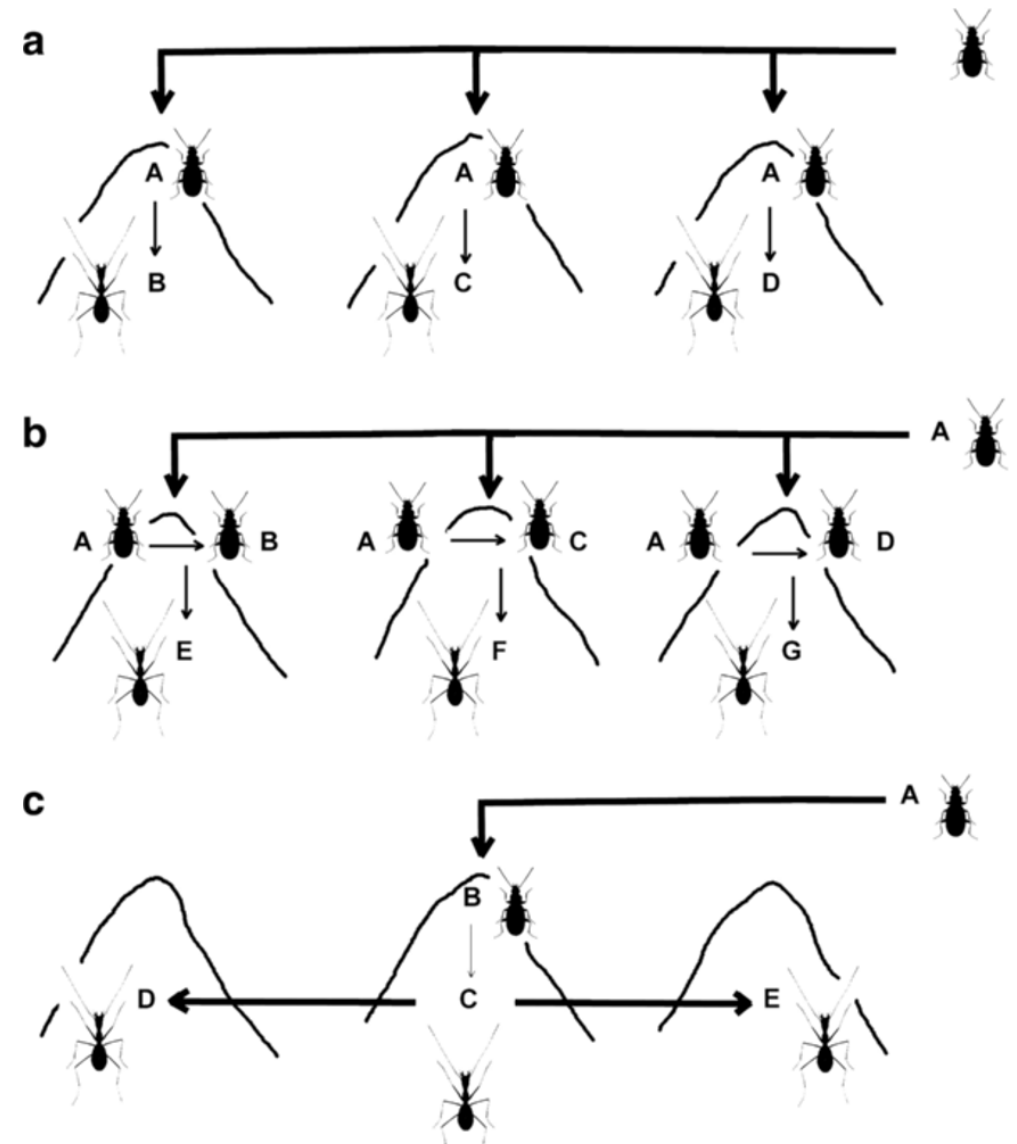

Figure 6 Simplified representation of three idealised scenarios of subterranean colonization leading to an extant monophyletic hypogean lineage (see Discussion). Different combinations of the three, in all possible degrees, can be found among the subterranean Trechini from the Alps. a: Three independent subterranean colonizations from a widespread epigean ancestor. b: Same as (a), but preceded by speciation of the epigean ancestor. The three resulting epigean species colonize independently the subterranean medium. c: Single subterranean colonization, with subsequent dispersal and diversification of the hypogean species.

the other hand could never be falsified - only made unlikely.

\section{Conclusions}

We have unveiled the complex history of a ground beetle lineage with multiple instances of independent colonisation of the subterranean world, showing that there is no simple, unique evolutionary pathway in which this could be achieved. Thus, among the Alpine fauna of Trechini we have recognised recent radiations with multiple origins of subterranean species (e.g. Duvalius, some lineages within Trechus); isolated, highly modified troglobitic genera of uncertain affinities (e.g. Doderotrechus, Speotrechus); and ancient, diverse lineages likely to have diversified and expanded once fully adapted to the underground life (the Dinaric-Alpine subterranean clade). It seems clear that the use of simplistic models may only lead to the artificial recognition of exclusive alternative hypotheses where there is a continuum of different processes. To understand the origin and evolution of the subterranean fauna it is thus necessary to comprehensively investigate the evidence provided by the phylogenetic and geographical context of each lineage individually.

\section{Methods}

\section{Taxon sampling, DNA extraction and sequencing}

Sampling was carried out in the Alps and nearby areas during 2011 and 2012. We included examples of all the endemic genera of hypogean Trechini from their entire known distribution area, with the only exception of Aphaenopidius and Duvaliaphaenops, of which no specimens could be obtained. Of the two Alpine genera with a widespread distribution (Duvalius and Trechus) numerous localities of hypogean and epigean species were sampled (Additional file 4: Figure S3; Additional file 5: Table S2). We also added some taxa from other geographical areas that have been related to the Alpine fauna (Pyrenees and Sardinia), plus two genera of hypogean 
Trechini from the Dinarides, one orophilous Himalayan species originally described as belonging to the genus Trechus, and a sample of the genera Pheggomisetes and Jeannelius from the Balkans and the Caucasus respectively. In total, we analysed 207 individuals of 173 species belonging to 31 genera (Additional file 5: Table S2, where authors and year of description of the studied species can also be found). Specimens were collected by hand or by means of pitfall traps containing propylene glycol, known to preserve DNA [66,67], and subsequently preserved in $96 \%$ ethanol. For some species we extracted DNA from dried specimens deposited in the ZSM. Extractions of single specimens were non-destructive, using the DNeasy Blood \& Tissue Kit (Qiagen GmbH, Hilden, Germany). After extraction, specimens were mounted on cards and genitalia stored in water-soluble dimethyl hydantoin formaldehyde (DMHF) on transparent cards, pinned beneath the specimen. Vouchers and DNA aliquotes are stored in the collections of ZSM, IBE and MNHN.

The tree was rooted with a species of Patrobini (Penetretus temporalis), found to be sister to Trechinae (or Trechitae) $[28,43]$. In preliminary analyses other Trechini outgroups closer to Trechina (as e.g. Trechodina, Perileptus or Thalassophilus) were found to have extremely long branches and were not used to avoid analytical artifacts. The topologies obtained were, however, very similar (results not shown).

We amplified fragments of four mitochondrial genes: 3 ' end of cytochrome c oxidase subunit $(\operatorname{cox} 1)$ and a single fragment including the $3^{\prime}$ end of the large ribosomal unit $(r r n L)$, the whole tRNA-Leu gene $(\operatorname{trnL})$ and the $5^{\prime}$ end of the NADH dehydrogenase 1 (nad1). We also amplified two nuclear genes, an internal fragment of the large ribosomal unit $28 \mathrm{~S}$ rRNA $(L S U)$ and the $5^{\prime}$ end of the small ribosomal unit 18S rRNA (SSU) (see Additional file 6: Table S3 for the primers used). Sequences were assembled and edited using Sequencher TM 4.8 (Gene Codes, Inc., Ann Arbor, MI). Some sequences were obtained from Faille et al. [9,13] (Additional file 5: Table S2). New sequences have been deposited in the EMBL database (Accession Numbers: Additional file 5: Table S2).

\section{Phylogenetic analyses}

We aligned the sequences using the MAFFT online v.6 with the Q-INS-i algorithm and default parameters [68]. Analyses were conducted on the combined data matrix with MrBayes 3.1.2 [69], using five partitions corresponding to the five genes used (the $\operatorname{trn} L$ and $r r n L$ genes were included in the same partition). We used jModelTest 3.7 [70] to identify the best model of nucleotide substitution fitting each gene (partition). Two independent analyses of MrBayes ran until convergence using default values, saving trees each 5,000 generations. 'Burn-in' values and convergence were determined through the effective sample size (ESS) in Tracer v1.5 [71]. Results of the two runs were combined using LogCombiner v1.4.7 and consensus trees were compiled with TreeAnnotator v1.4.7 (Drummond \& Rambaut 2007). Maximum likelihood analyses were conducted on the combined data matrix with RAxML GUI [72-74], using four partitions corresponding to the cox $1, r r n L+\operatorname{trn} L+n a d 1, S S U$ and $L S U$ fragments with a GTR $+\mathrm{I}+\mathrm{G}$ evolutionary model and default values for other parameters of the search [73].

\section{Estimation of divergence times}

We used the Bayesian relaxed phylogenetic approach implemented in BEAST v1.7 to estimate the age of divergence of the different clades [72,75]. We pruned the outgroups and implemented a GTR $+\mathrm{G}$ model of DNA substitution to the same partition by genes used in the phylogenetic analyses. We used as priors the rates estimated for the same gene fragments in [42] for a related group of ground beetles (genus Carabus) based on a set of fossils and biogeographic events. We sequenced three fragments not included in [42], nad1, trnL and SSU, for which we used the same rates as $\operatorname{cox} 1, r r n L$ and $L S U$ respectively. The rates used were a strict clock for the mitochondrial genes, with mean rates of 0.0145 for the genes $n a d 1$ and cox 1 and 0.0016 for the fragment $r r n L+$ trnL; and a lognormal clock with mean rates of 0.0010 and 0.0013 for the SSU and LSU genes respectively. We used a Yule process of speciation as the tree prior, sampled the chain each 5,000 generations and used TRACER to determine convergence, measure the effective sample size of each parameter and calculate the mean and 95\% highest posterior density interval for divergence times.

\section{Availability of supporting data}

All supporting data are included in the Supplementary files with the exception of the sequences, deposited in the EMBL database with accession numbers HG514501-HG514996, and the alignments and trees, deposited in tree BASE: http://purl.org/phylo/treebase/phylows/study/TB2:S14674.

\section{Additional files}

Additional file 1: Figure S1. Map of the main alpine karsts (in black) (modified from [17]).

Additional file 2: Figure S2. Lateral (a) and dorsal (b) views of a Trechini male genitalia, showing the anisotopic (1) and isotopic (2) positions of the copulatory piece (modified from [2]).

Additional file 3: Table S1. List of the genera of Alpine Trechini, including number of species and previous hypotheses of relationships $[2,11-13,20,22-25,27,30,46,47,76-83]$.

Additional file 4: Figure S3. Map of the sampled localities.

Additional file 5: Table S2. Material used in the study, with locality data, voucher number and accession numbers of the sequences.

Additional file 6: Table S3. Primers used in the PCR amplification. 


\section{Competing interest}

The authors declare that they have no competing interest.

\section{Authors' contributions}

$A F, A C$ and $I R$ conceived the study. AF and AC coordinated the sampling. AF obtained the sequences. All authors contributed materials/reagents. AF and IR did the analyses and drafted the manuscript. All authors contributed to the writing and improving the manuscript, and approved the final version.

\section{Acknowledgements}

We are particularly indebted to numerous colleagues and friends for their invaluable help and constant support in sampling specimens of many of the species studied in this contribution, most of them with narrow distributions and often restricted to localities of very difficult access (caves, high mountains). In particular, we wish to thank Charles Bourdeau, Hervé Bouyon, Petr Bulirsch, Gianfranco Caoduro, Dávid Čeplíck, Alain Coache, Giorgio Colombetta, Louis Deharveng, Thierry Deuve, Giorgio Fornasier and all the members of the Unione Speleologica Pordenonese, Javier Fresneda, Fulvio Gasparo, Michael Geiser, Mario Grottolo, Pier Mauro Giachino, Bernard Junger, Manfred Kahlen, Alexandr Koval, Ján Lakota, Enrico Lana, Leonardo Latella, Jean-Michel Lemaire, Roman Lohaj, Paolo Magrini, Paolo Marcia, Harald Mixanig, Roman Mlejnek, Riccardo Monguzzi, Vittorino Monzini, Carlo Onnis, Alessandro Pastorelli, Erminio Piva, Jean Raffaldi, Jean Raingeard, Jose Maria Salgado, Joachim Schmidt, and Dante Vailati. We also sincerely thank Alberto Ballerio (Brescia) for his very helpful support with the ICZN, which allowed us to confirm the generic name Aphaenops (corrected to Aphoenops in recent catalogues) as nomen protectum and conservandum in agreement with articles 33.2.3.1 and 33.3.1 of the Code.

Although none of the species sampled is included in international lists for the conservation of endangered species of wild fauna (Annexes of the Habitat Directive 92/43/EEC, Berna Convention or CITES), we thank the local administrations, speleological associations or responsibles of Natural Parks for the licenses to access closed, touristic or protected areas or caves. License for the subterranean taxa protected in France was obtained as specified in [9] (arrêtés N²003-06, 25/2003, 2004-01). We thank Diego Lonardoni (Director of the the Lessinia Natural Parc, Verona, Italy) for his authorisation to conduct scientific investigations in this area and Slavko Polak (Notranjski muzej Postojna) for his support in sampling in some Slovenian caves. We also thank the ZSM for allowing the use of specimens of the Daffner collection for DNA extractions, Enrico Lana for the picture of Italaphaenops dimaioi and two anonymous referees for comments to the manuscript. This work has been partly funded by an Alexander von Humboldt Foundation grant and German Research Foundation projects (BA2152/14-1 and FA 1042/1-1), the Italian PRIN (Research Programmes of National Interest, University of Sassari) "The endemism in Italy" and the R.A.S. Project CRP-60215 (2012) "Conservation and valorisation of the Sardinian caves: biodiversity and social, cultural and economic rules" to AC, and project CGL2010-15755 from the Spanish government to IR.

\section{Author details}

${ }^{1}$ Zoologische Staatsammlung, Muenchhausenstrasse 21, Munich 81247, Germany. ${ }^{2}$ Dipartimento di Scienze della Natura e del Territorio, Sez. Zoologia, Università di Sassari, Via Muroni 25, Sassari 07100, Italy. ${ }^{3}$ Institute of Evolutionary Biology (CSIC-Universitat Pompeu Fabra), Passeig Maritim de la Barceloneta 37-49, Barcelona 08003, Spain.

Received: 8 June 2013 Accepted: 8 October 2013

Published: 13 November 2013

\section{References}

1. Vandel A: Biospéologie. La Biologie des Animaux Cavernicoles. Paris: GauthierVillars; 1964

2. Jeannel R: Monographie des Trechinae. Morphologie comparée et distribution d'un groupe de Coléoptères. Troisième Livraison: les Trechini cavernicoles. L'Abeille 1928, 35:1-808.

3. Casale A, Vigna Taglianti A, Juberthie C: Coleoptera Carabidae. In Encyclopaedia Biospeologica. Volume 2nd edition. Edited by Juberthie C, Decu V. Moulis-Bucarest: Société Internationale de Biospéologie; 1998:1047-1081.

4. Giachino PM, Vailati D, Casale A: Major questions in the phylogeny and biogeography of Cholevidae (Coleoptera), with emphasis on the subfamily Leptodirinae. In Phylogeny and evolution of subterranean and endogean Cholevidae (= Leiodidae, Cholevinae) Proceedings of XX International Congress of Entomology, Firenze, 1996. Edited by Giachino PM, Peck SB. Torino: Atti Museo Regionale di Scienze Naturali; 1998:179-209.

5. Racovitza EG: Essai sur les problèmes biospéologiques. Arch Zool Exp Gen (4ème sér.) 1907, 6:371-488.

6. Jeannel R: Les fossiles vivants des cavernes. Paris: Gallimard; 1943.

7. Culver DC: Analysis of simple cave communities. I. Caves as islands. Evolution 1970, 24:463-474.

8. Wiens JJ, Chippindale PT, Hillis DM: When Are phylogenetic analyses misled by convergence? a case study in texas cave salamanders. Syst Biol 2003, 52(4):501-514.

9. Faille A, Ribera I, Deharveng L, Bourdeau C, Garnery L, Quéinnec E, Deuve T: A molecular phylogeny shows the single origin of the Pyrenean subterranean Trechini ground beetles (Coleoptera: Carabidae). Mol Phylogenet Evol 2010, 54:97-105.

10. Ribera I, Fresneda J, Bucur R, Izquierdo A, Vogler AP, Salgado JM, Cieslak A: Ancient origin of a western Mediterranean radiation of subterranean beetles. BMC Evol Biol 2010, 10(29):1-14. doi:10.1186/1471-2148-10-29.

11. Quéinnec E, Ollivier E: Tribu Trechini. In Faune de France 94. Coléoptères carabiques, compléments et mise à jour, Volume 1. Edited by Coulon J, Pupier R, Quéinnec E, Ollivier E, Richoux P. Paris: Fédération française des Sociétés de Sciences Naturelles; 2011:119-254.

12. Moravec P, Uéno SI, Belousov IA: Carabidae: Trechinae: Trechini. In Catalogue of Palaearctic Coleoptera, Volume 1. Edited by Löbl I, Smetana A. Stenstrup: Apollo Books; 2003:288-346.

13. Faille A, Casale A, Ribera I: Phylogenetic relationships of west Mediterranean troglobitic Trechini ground beetles (Coleoptera: Carabidae). Zool Scr 2011, 40(3):282-295.

14. Casale A, Vigna Taglianti A: Coleotteri caraboidei delle Alpi e Prealpi centrali e orientali, e loro significato biogeografico (Coleoptera, Caraboidea). Biogeographia 2005, 26:129-201.

15. Culver DC, Deharveng L, Bedos A, Lewis JJ, Madden M, Reddell JR, Sket B, Trontelj P, White D: The mid-latitude biodiversity ridge in terrestrial cave fauna. Ecography 2006, 29:120-128.

16. Ozenda P, Borel JL: The Alpine Vegetation of the Alps. In Alpine Biodiversity in Europe. Ecological Studies 167. Edited by Nagy L, Grabherr G, Körner C, Thompson DBA. Berlin Heidelberg: Springer; 2003:53-64.

17. Audra P, Bini A, Gabrovšek F, Häuselmann P, Hobléa F, Jeannin PY, Kunaver J, Monbaron M, Šušteršič F, Tognini P, Trimmel H, Wildberger A: Cave and karst evolution in the Alps and their relation to paleoclimate and paleotopography. Acta carsologica 2007, 36(1):53-67.

18. Casale A, Vigna Taglianti A: I coleotteri carabidi delle Alpi occidentali e centro-occidentali (Coleoptera, Carabidae). Biogeographia 1993, 16(1992):331-399.

19. Casale A, Vigna Taglianti A: I coleotteri carabidi delle Alpi Liguri. Composizione della fauna ed origine del popolamento. Lav Soc ital Biogeog (ns) 1985, 9(1982):567-598.

20. Vigna Taglianti A: Le attuali conoscenze sui coleotteri carabidi cavernicoli italiani. Lav Soc Ital Biogeogr (ns) 1982, 7(1978):339-430.

21. Vigna Taglianti A: Checklist e corotipi delle specie di Carabidae della fauna italiana. Appendice B. In / Coleotteri Carabidi per la valutazione ambientale e la conservazione della biodiversità. Manuale operativo. APAT, Manuali e Linee Guida. 34th edition. Edited by Brandmayr P, Zetto T, Pizzolotto R. Roma: APAT; 2005:186-225.

22. Lorenz W: Systematic list of extant ground beetles of the world (Insecta Coleoptera "Geadephaga": Trachypachidae, and Carabidae incl. Paussinae, Cicindelinae, Rhysodinae). Secondth edition. Tutzing: published by the author; 2005.

23. Jeannel R: Faune de France. Vol. 39: Coléoptères carabiques I. Paris: Lechevalier; 1941.

24. Casale A, Vigna Taglianti A: Note su Italaphaenops dimaioi Ghidini (Coleoptera, Carabidae). Boll Mus Civ Stor Nat Verona 1975, 2:293-314.

25. Vigna Taglianti A, Sciaky R: Il genere Lessinodytes Vigna Taglianti, 1982 (Coleoptera, Carabidae, Trechinae). Fragm Entomol 1988, 20(2):159-180.

26. Monguzzi R: Studi sul genere Boldoriella Jeannel: sistematica, geonemia, ecologia (Coleoptera, Carabidae, Trechinae). Atti Soc Ital Sci Nat Mus Civ Stor Nat Milano 1982, 123(2-3):189-236.

27. Monguzzi R: Sintesi delle attuali conoscenze sul genere Allegrettia Jeannel, 1928 (Coleoptera, Carabidae, Trechinae). Ann Mus Civ Stor Nat 'Giacomo Doria' 2011, 103:1-70. 
28. Grebennikov W, Maddison DR: Phylogenetic analysis of Trechitae (Coleoptera: Carabidae) based on larval morphology, with a description of first-instar Phrypeus and a key to genera. Syst Entomol 2005, 30:38-59.

29. Jeannel R: Monographie des Trechinae 2. Morphologie comparée et distribution géographique d'un groupe de coléoptères. L'Abeille 1927, 33:1-592.

30. Casale A, Laneyrie R: Trechodinae et Trechinae du monde. Tableau des sous-Familles, Tribus, séries phylétiques, genres, et catalogue général des espèces. Mem Biospeol 1982, 9:1-226.

31. Schmidt J: Taxonomic and biogeographical review of the genus Trechus Clairville, 1806, from the Tibetan Himalaya and the southern central Tibetan plateau (Coleoptera: Carabidae: Trechini). Zootaxa 2009, 2178:1-72.

32. Deuve T: La vie déserticole dans le genre Duvalius Delarouzée, 1854. Description d'une forme macroptère du Golfe Persique [Coleoptera, Trechidae]. Revue Française d'Entomologie 2000, 22(4):159-163.

33. Magrini P: Première révision des Duvalius s. str. Italiens (Coleoptera, Carabidae, Trechinae). Les Comptes-rendus du L.E.F.H.E. 1997, 2:202-292.

34. Magrini P: Première révision des Duvalius s. str. Italiens (deuxième partie: atlas biogéographique des Duvalius Italiens; ajouts et corrections de la première partie) (Coleoptera, Carabidae, Trechinae). Les Comptes-rendus du L.E.F.H.E 1998, 3:55-149.

35. Culver DC, Sket B: Hotspots of subterranean biodiversity in caves and wells. J Cave Karst Stud 2000, 62:11-17.

36. Lohaj R, Lakota J: Two new genera and species of aphaenopsoid cave-dwelling Trechini beetles from Croatia and Montenegro (Coleoptera: Carabidae: Trechinae). Natura Croatica 2010, 19(1):77-97.

37. Casale A, Jalžić B, Lohaj R, Mlejnek R: Two new highly specialised subterranean beetles from the Velebit massif (Croatia): Velebitaphaenops (new genus) giganteus Casale \& Jalžić, new species (Coleoptera: Carabidae: Trechini) and Velebitodromus ozrenlukici Lohaj, Mlejnek \& Jalžić, new species (Coleoptera: Cholevidae: Leptodirini). Nat Croat 2012, 21:129-153.

38. Lohaj R, Mlejnek RA: New species of the genus Acheroniotes Lohaj \& Lakota from Ljubišna Mts, Bosnia \& Herzegovina (Coleoptera: Carabidae: Trechini). Natura Croatica 2012, 21(1):155-163.

39. Monguzzi R: Note sul "gruppo di Trechus strigipennis" con descrizione di una nuova specie (Coleoptera Carabidae). Bollettino della Societò entomologica italiana 1998, 130:199-220.

40. Casale A: Nuovi Carabidi di Marocco, di Grecia e di Papua - Nuova Guinea (Coleoptera). Rev Suisse Zool 1982, 89:229-244.

41. Vigna Taglianti A: Un nuovo Doderotrechus cavernicolo delle Alpi Occidentali (Coleoptera, Carabidae). Fragm Entomol 1969, 6:253-269.

42. Andújar C, Serrano J, Gómez-Zurita J: Winding up the molecular clock in the genus Carabus (Coleoptera: Carabidae): assessment of methodological decisions on rate and node age estimation. BMC Evol Biol 2012, 12:40. doi:10.1186/1471-2148-12-40.

43. Maddison DR, Ober KA: Phylogeny of minute carabid beetles and their relatives based upon DNA sequence data (Coleoptera, Carabidae, Trechitae). Zookeys 2011, 147:229-260. doi: 10.3897/zookeys.147.1871 DOI:10.3897\%2Fzookeys.147.1871.

44. Daffner H: Orotrechus haraldi n.sp. aus Kärnten - Austria (Coleoptera, Carabidae, Trechinae). Acta Coleopterologica 1990, 6(2):51-60.

45. Monguzzi R, Trezzi G: Note sul "Gruppo di Orotrechus gigas Vigna Taglianti, 1981", sensu novo, con descrizione di una nuova entità (Coleoptera Carabidae). Fragm Entomol 2005, 37(1):9-31.

46. Kurnakov VN: Les Trechini de la faune souterraine de l'Abkhazie. Revue Française d'Entomologie 1959, 26:231-236.

47. Makarov KV, Koval AG: A contribution to the knowledge of the biology of a troglobiont carabid Jeannelius birsteini Ljovuschkin, 1963 (Coleoptera, Carabidae, Trechini). Entomol Obozr 2003, 82(4):836-845 (in Russian).

48. Jeannel R: Révision des Trechini du Caucase (Coleoptera, Trechidae). Mém Mus Nation Hist Nat Série A 1960, 17(3):155-216.

49. Casale A: Revisione degli Sphodrina (Coleoptera, Carabidae, Sphodrini). Monografie 5. Torino: Museo regionale di Scienze naturali; 1988.

50. Müller J: I coleotteri della Venezia Giulia. Catalogo ragionato. Parte I: Adephaga. Studi entomologici, Trieste 1926, 1(2):1-306.

51. Drioli G: Anophthalmus hirtus stygius n. ssp. ed osservazioni morfologiche sul "rassenkreis" dell'Anophthalmus hirtus Sturm (Coleoptera Carabidae). Gortania - Atti Museo Friul Storia nat 1981, 3:245-270.
52. Sciaky R: Proposte sulla Sistematica del genere Anophthalmus e descrizione di tre nuove sottospecie del Friuli orientale (Coleoptera, Carabidae, Trechinae). Fragm Entomol 1987, 20(1):51-69.

53. Daffner H: Revision der Anophthalmus-Arten und -Rassen mit lang und dicht behaarter Korperoberseite (Coleoptera, Carabidae, Trechinae). Mitt Muench Entomol Ges 1996, 86:33-78.

54. Daffner H: Die Arten und Rassen der Anophthalmus schmidti und -mariae Gruppe (Coleoptera: Carabidae: Trechinae). Acta Entomol Slovenica 1998, 6(2):99-128

55. Daffner H: Die Arten der Gattung Arctaphaenops Meixner, 1925 (Coleoptera: Carabidae). Koleopterol Rundsch 1993, 63:1-18.

56. Assmann T, Casale A, Drees C, Habel JC, Matern A, Schuldt A: Review: The dark side of relict species biology: cave animals as ancient lineages. In Relict species: phylogeography and conservation biology. Edited by Habel JC, Assmann T. Heidelberg: Springer; 2010:91-103.

57. Hampe A, Jump AS: Climate relicts: Past, present, future. Annu Rev Ecol Evol Syst 2011, 42:313-33.

58. Juberthie C, Delay B, Bouillon M: Extension du milieu souterrain en zone non calcaire. Description d'un nouveau milieu et de son peuplement par les coléoptères troglobies. Mem Biospeol 1980, 7:19-52.

59. Juberthie C, Bouillon M: Présence des Aphaenops (Coléoptères Trechinae) dans le milieu souterrain superficiel des Pyrénées françaises. Mem Biospeol 1983, 10:91-98.

60. Giachino PM, Vailati D: The subterranean environment. Hypogean life, concepts and collecting techniques. WBA Handbooks - Vol. 3. Verona: World Biodiversity Association onlus; 2010

61. Rizzo V, Comas J, Fadrique F, Fresneda J, Ribera I: Early Pliocene range expansion of a clade of subterranean Pyrenean beetles. J Biogeogr. In press.

62. Popov SV, Rögl F, Rozanov AY, Steininger FF, Shcherba, Kovac M: Lithological-Paleogeographic maps of Paratethys. 10 Maps late Eocene to Pliocene. Courier Forschungsinstitut Senckenberg 2004, 250:1-46.

63. Casale A: Two new subterranean, microphthalmous trechine beetles from the Mediterranean area, and a synonymic note (Coleoptera: Carabidae, Trechini). Contributions to Natural History 2011, 16:1-16.

64. Jeannel R: Etude sur le Trechus fulvus Dej. Sa phylogénie, son intérêt biogéographique. Trabajos del Museo Nacional de Ciencias Naturales, Serie Zoologica 1920, 41:1-25.

65. Erhard C, Spötl C: Karst geology and cave fauna of Austria: a concise review. Int J Speleol 2010, 39(2):71-90.

66. Rubink WL, Murray KD, Baum KA, Pinto MA: Long term preservation of DNA from honey bees (Apis mellifera) collected in aerial pitfall traps. Tex. J. Sci 2003, 55:159-168.

67. López H, Oromí P: A pitfall trap for sampling the mesovoid shallow substratum (MSS) fauna. Speleobiology Notes 2010, 2:7-11.

68. Katoh K, Toh H: Recent developments in the MAFFT multiple sequence alignment program. Briefings Bioinformatics 2008, 9:286-298.

69. Huelsenbeck JP, Ronquist F: MRBAYES: bayesian inference of phylogenetic trees. Bioinformatics 2001, 17:754-755.

70. Posada D: JModelTest: phylogenetic model averaging. Mol Biol Evol 2008, 25:1253-1256.

71. Drummond AJ, Rambaut A: BEAST: bayesian evolutionary analysis by sampling trees. BMC Evol Biol 2007, 7:214.

72. Stamatakis A, RAxML-VI-HPC: Maximum likelihood-based phylogenetic analyses with thousands of taxa and mixed models. Bioinformatics 2006, 22(21):2688-2690.

73. Stamatakis A, Hoover $P$, Rougemont J: A rapid bootstrap algorithm for the RAxML web-servers. Syst Biol 2008, 75(5):758-771.

74. Silvestro D, Michalak I: RaxmIGUI: a graphical front-end for RAxML. Org Divers Evol 2012, 12:335-337. doi:10.1007/s13127-011-0056-0.

75. Drummond AJ, Suchard MA, Xie D, Rambaut A: Bayesian phylogenetics with BEAUti and the BEAST 1.7. Mol Biol Evol 2012, 29:1969-1973.

76. Bucciarelli I: Quattro nuove Boldoriella ed osservazioni sull'habitat (Coleoptera Carabidae). Mem Soc Entomol Ital 1978, 56(1977):217-228.

77. Vigna Taglianti A: Un nuovo genere di Trechinae endogei e cavernicoli delle Alpi Occidentali (Coleoptera, Carabidae). Fragm Entomol 1968, 5:181-201.

78. Casale A: Coleotteri ipogei ed endogei (Carabidae Anillini, Trechini e Sphodrini, Catopidae Bathysciinae) delle Alpi Cozie e Graje (versante italiano). Mem Biospeol 1980, 7:53-61.

79. Ghidini GM: Un nuovo eccezionale Trechino cavernicolo italiano: Italaphaenops dimaioi n. gen., n. sp. (Coleoptera: Trechidae). Boll Soc entomol ital 1964, 94:32-36. 
80. Caoduro G, Osella G, Ruffo S: La fauna cavernicola della regione veronese. Memorie del Museo civico di Storia naturale di Verona, (lla serie), sezione Scienze della Vita (A: Biologica) 1994, 11:1-145.

81. Gestro R: Nuovi materiali per lo studio degli Anophthalmus italiani. Ann Mus Civ St Nat Genova 1892, 32:79-85.

82. Drovenik B: Eine neue Art der Gattung Aphaenopidius Müller 1913 (Coleoptera: Carabidae: Trechinae). Entomol Z Insektenborse 1987, 97(5):49-64.

83. Winkler A: Eine zweite höhlenlaufkäferart aus den nordalpen: arctaphaenops styriacus sp. n. Koleopterol Rundsch 1933, 19:237-240.

doi:10.1186/1471-2148-13-248

Cite this article as: Faille et al:: A molecular phylogeny of Alpine subterranean Trechini (Coleoptera: Carabidae). BMC Evolutionary Biology 2013 13:248.

\section{Submit your next manuscript to BioMed Central and take full advantage of:}

- Convenient online submission

- Thorough peer review

- No space constraints or color figure charges

- Immediate publication on acceptance

- Inclusion in PubMed, CAS, Scopus and Google Scholar

- Research which is freely available for redistribution 